\section{The Concept of Plea Bargain in an Ethical Society}

\section{Denisa BARBU ${ }^{1}$}

${ }^{1} \mathrm{PhD}$. Lecturer, Public Administration Department, Faculty of Law and Administrative Sciences, Valahia University of Târgovişte, denisa.barbu77@yahoo.com

\begin{abstract}
The current Criminal Procedure Code has introduced several elements specific to adversarial law. Among these specific elements, I consider that a special impact on those interested in or targeted by the dispositions of criminal law is "negotiated justice". Traditionally, in the field of criminal procedural law, several institutions specific to the continental system have been adopted in our country, that impose for the diagnosis of the legal problem, so that in criminal procedural law the objective truth must be identical to the judicial truth, hence the fact that judges can't base their rulings on anything else than actual facts. During the evolution of civilization, three criminal procedural systems have appeared progressively, in a chronological (historical) order in full accordance with the political and social tendency of the states at a certain moment, namely the inquisitorial system, the accusatory system, respectively the mixed system, named the continental system. We will resort in the following article to a brief presentation of these criminal procedural systems, while making a brief analysis of each of them.
\end{abstract}

Keywords: plea bargain, procedure, accusation, defendant.

How to cite: Barbu, D. (2020). The Concept of Plea Bargain in an Ethical Society. Journal for Ethics in Social Studies, 4(1), 21-30.

https://doi.org/10.18662/jess/4.1/25 


\section{Introduction}

Although it would seem that determining the active role of the prosecutor is not an easy operation, the duties of the magistrate in question can be determined differently regarding his attributions depending on the legal tradition adopted in a given country. Two types of legal traditions dominate the nature of investigation and trial worldwide: the accusatory and inquisitorial legal systems.

A specificity of the adversarial system of law (Fisher, 2007, p. 947; Văduva, 2019, p. 2), in addition to the fact that there is the possibility to negotiate the punishment itself, is the option of the defendant to negotiate with the prosecutor the charge levelled against them. According to this system, in exchange for the defendant's plea of guilt in respect of other offenses they committed, the prosecutor has the option of limiting the charge by waiving the defendant's charges.

From the detailed analysis of the concept of "inquisitorial system", we appreciate that with the emergence of this system it was established that no settlement of a dispute between the state, through the judiciary and the accused, can be allowed, because this system is characterized by the pursuit to discover the objective truth at any cost, which means that the punishment applied must clearly reflect the seriousness of the harm the defendant has caused to society. This denotes that the inquisitorial system has a remarkable contribution to the strict observance of the general interest of society, while the interest of the accused person does not prevail.

After making a small comparison between the two legal systems analyzed above, we appreciate that the inquisitorial system better represents the principle of equality of citizens before the law, as the possibilities of the accused to engage in confrontation with the prosecution do not determine in any way the outcome of the trial.

Both systems have variations around the world, as many countries have changed their criminal procedure in various ways over the years, balancing the interests of the state in detaining and prosecuting criminals with the interests of individual citizens who may be involved in the criminal proceedings.

We conclude that each of these two legal systems has been characterized by both qualities and defects, neither of which is sufficiently effective in ensuring and guaranteeing an appropriate criminal justice.

Therefore, at the beginning of the century nineteenth century, the continental system was born within the legal systems of Europe, which was 
also called the mixed system. This continental system built its foundations by rationally combining the characteristics and guarantees of the two fundamental systems mentioned above, given the legislative interests reflected in the criminal policies at that time (Crişu, 2017, p. 10; Văduva, 2019, p. 4 ).

The analysis of the regulations contained in the New Criminal Procedure Code shows that Romania adopted the continental system, attracting rules that are both specific to the adversarial system and to the inquisitorial system, thus being perceived as a mixed system of law.

The purely continental system is hostile to the notion of negotiated justice, considering that a person's guilt can be established only after the judge administers the evidence, and the criminal liability of the defendant cannot be the subject of any agreement between the defendant and the prosecutor. Starting with the 19th century, the Anglo-American system recognized at a slow pace the possibility for the defendant to plea guilty and to conduct the trial based on that plea, later accepting the possibility of initiating a negotiation between the defendant and the prosecutor, that could be followed by the completion of a plea bargain (Ghigheci, 2014, pp. 22-24; Iugan, 2015, p. 9).

When analyzing the emergence and development of the concept of "negotiated justice" in the representative adversarial system of law, the criminal procedural law system of the United States of America is depictive, as portrayed by the institution of "plea bargaining", which represents an important source of inspiration for all criminal procedural systems that are of continental origin.

In the U.S. criminal law system, the institution of "bargaining" was effectively used even before this institution was accepted by the Supreme Court of Justice. In 1970 it was accepted as a form of justice by the Supreme Court with the ruling in the case of Brady vs. U.S.A.

During the nineteenth and twentieth centuries, US Supreme Court found that the practice of judicial bodies by which advantages were granted to the accused was unconstitutional. Although the Court expressly opposed the advantages granted in exchange for a plea bargain, those involved in the administration of the act of justice negotiated in such a way that they were able to turn this institution into a phenomenon which could not be rejected by the Court. The institution of "plea bargaining", in its currently regulated form, became important in the nineteenth century, but this does not mean that until then the defendant's admission of guilt was extraneous to the American legal system (Văduva, 2019, p. 8). 


\section{Aspects regarding the emergence and evolution of the notion of plea bargain}

The plea bargain, as a criminal procedural institution, has been approached in recent years through a detailed analysis, its evolution being unstable, oscillating between the solutions issued by the competent courts, on the one hand, and the views of the legal doctrine expressed regarding criminal cases, on the other hand. In the immediate sense, this institution was regulated as an element of novelty in the field of criminal proceedings with the entry into force of the New Criminal Procedure Code in 2014.

As already mentioned, the origin of the plea bargain must be tracked down in the adversarial law systems, where this institution has known a relatively long practice, under the title of plea bargaining or quality plea.

By Law no. 202/2010 regarding some measures to expedite the judgement of trials, art. 320 was introduced in the old Criminal Procedure Code, which provided for the possibility to resort to a simplified procedure during the trial phase. This simplified procedure could be carried out on the basis of the statement given by the defendant acknowledging that he had committed the offenses as shown by the prosecuting authorities in the document instituting the proceedings, while, at the same time, it is required that the criminal proceedings be conducted based on the evidence administered by the criminal investigation bodies (Iugan, 2015, p. 9).

Subsequently, following a decision of the Constitutional Court of Romania (2011), paragraphs 4 and 8 of article 320 were amended by Government Emergency Ordinance no. 121/2011.

Thus, the criminal procedure legislation has undergone a series of major changes with the entry into force of the New Criminal Procedure Code, changes that have an eloquent role so that they manage to align the legal system with social realities and increase the quality and expeditiousness of criminal proceedings agreement, while ensuring the respect for and guarantee of fundamental human interests, rights and freedoms.

Although the institution of the plea bargain is a novelty in the Romanian legislation, it is experienced by the legislation of several European countries, being a means of inspiration for the Romanian legislator, who adopted it and took from these legislations several provisions determining the purpose of this legal institution. Thus, similar provisions have been implemented by countries such as France or Germany.

In the Romanian legislation, all the normative acts specific to the continental system were adopted with the exact observance of the principle of legality and the principle of finding out the truth. It should be noted that 
these principles cannot be considered compatible with the adversarial system. This argument is based on the following ideas: the principle of finding out the truth establishes the obligation of the judicial bodies to go through all the steps necessary in order to find out the truth in a criminal case, and the principle of legality presupposes establishing the guilt of the defendant and applying the punishment. Compared to these considerations, it was found that there can be no negotiation between defense and prosecution in a governmental criminal procedure system based on these two fundamental principles (Volonciu \& Nicolae Uzlău, 2017, p. 1373).

Although, obviously, the negotiation of the punishment between the prosecution and the defense would undermine the principle of legality and the truth, the special procedure of the plea bargain imposes certain requirements at the time of concluding the agreement between the prosecutor and the defendant by the censoring of such an agreement by the court and by ensuring sufficient guarantees regarding the observance of the stated principles (Olariu, 2019, p. 290; Volonciu et al., 2016, p. 304).

The analyzed institution is not without criticisms, as among the direct effects / consequences it produces we list, without being exhaustive, the elimination of the solemnity that accompanies the act of justice, the inequality of the citizens before the law, the reduction of the educational role of the criminal trial etc.

The legal concept of guilt is based on a series of rules that imply certain duties that the state must respect, through the judiciary bodies, namely the respect for the fundamental rights of the defendant, and, on the other hand, the defendant's option to use this procedure in order to admit their guilt regarding the deeds he was indicted with in the by the ordinance to initiate the criminal action and to assume the consequences of their deeds in accordance with the legal provisions (Magherescu, 2019, p. 13).

Also, it is imperative to distinguish between using the notion of guilt in various circumstances, because in the case of pleading guilty, the meaning of the term guilt is not the same as in art. 16 of the Criminal Code, but presupposes an acceptance / assumption of a factual situation that results from the evidence administered by the judicial bodies at the moment of hearing the defendant. Although the defendant is informed about the possibility of concluding the plea bargain, the defendant's decision to conclude such an agreement does not constitute a means of proof in any form and is not related to establishing the factual situation (Bârsan \& Cardiş, 2015, p. 28).

Moreover, we must keep in mind that such a plea bargain should not be confused in any way with a confession made by the defendant, being 
considered neither evidence nor a means of proof, but only a simple legal means to shorten the duration of the trial, as a result of the will of the interested party to plead guilty in the case (Bârsan \& Cardiş, 2015, p. 29; Cotoi \& Brutaru, 2014, p. 13).

As it appears from the Romanian legislation, but also from the legislation of other states, even if they are part of the Anglo-Saxon system or the Romano-German system, in all cases the recognition of guilt must be freely expressed and consented to. A recognition of guilt made by the defendant under pressure exerted by the investigative team is obviously invalid. Moreover, a tacit recognition made by the defendant cannot be accepted during criminal proceedings, given that by acknowledging their guilt, the defendant means to waive the right not to incriminate himself, so we cannot deduce the admission of guilt by interpreting what might be just a simple attitude of the defendant during the criminal proceedings or the criminal trial (Cotoi \& Brutaru, 2014, p. 30).

\section{The importance of the special character of the plea bargaining procedure}

Given the shortcomings in the old Criminal Procedure Code, corroborated with the requirements imposed by the institutions of the European Union and the European Court of Human Rights, the Romanian legislator improved the legal framework for solving criminal cases in all phases of the criminal proceedings.

Consequently, with the entry into force of the New Criminal Procedure Code, this legal institution specific to the adversarial system was introduced, implying a major change in the conduct of criminal proceedings. The plea bargain, as a legal institution, is new in the Romanian legislation, considering that in different countries this same institution is topical, as it is frequently found in the practice of the courts.

Although the plea bargain is a novel legal institution in the Romanian legal system, the Romanian legislator decided not to define the concept behind this institution, while expressly indicating in the Criminal Procedure Code only the framework for using this procedure, therefore the legal doctrine was left to establish a definition of this institution specific to criminal procedural law.

The analysis of the legal provisions shows that the procedure of the plea bargain can be defined as a special procedure, which derogates from the rules of common law, which applies only to certain offenses of low gravity and which also requires a perfect understanding between the defendant and 
the case prosecutor. In this procedure, the defendant acknowledges committing the deed he was charged with, and also accepts its legal classification, while the prosecutor agrees with a sentence as established during the negotiations with the defendant (Buneci et al., 2014, p 575; Pascu \& Manea, 2015, p. 20).

From a first detailed analysis, it was assessed that the institution in question may in fact be only a right that is conferred to the defendant in the course of criminal proceedings, namely the right to recognize the acts or facts retained by the charge brought against him. Thus, only in the event that the admission of guilt produces legal effects and implicitly this special procedure is followed, which finalizez in concluding a plea bargain, we can refer to the recognition of guilt by the defendant as a procedural institution, and not as a right recognized to the defendant, that he benefits from (Magherescu, 2019, p. 5).

From a teleological point of view, it should be noted that the notion of plea bargain represents the agreement between the representative of the Public Ministry and the person accused of committing a crime, namely the defendant (Bârsan \& Cardiş, 2015, p. 31; Pradel, 2005, p. 473 ). We can see that this procedure aims both to shorten the time needed to finalize criminal proceedings and to encourage collaboration with the representatives of the Public Ministry.

It must be emphasized that the plea bargain has the merit of resolving the conflict placed under the rule of criminal law in an expeditious manner, as a result of the will of the defendant in question. From the analysis of the jurisprudence in criminal cases, it is possible to observe a significant number of cases when the conclusion of the plea bargain was conducted in relation to the cases when the defendants exercised one of their fundamental rights in the criminal trial, namely the right to silence, aiming through this to the settlement of the criminal proceedings by the common law procedure.

\section{Conclusions}

From all these mentioned above we can appreciate that the importance of the institution of the plea bargain consists in accelerating the settlement of criminal cases, granting a series of benefits to all participants in the criminal proceedings, therefore, of course that the advantages of this institution must be analyzed from the perspective of both sides implicated in the criminal proceedings. 
First, the plea bargain appears to be an exclusive right of the defendant, and not of the suspect, since the incidence of this procedure necessarily involves the initiation of criminal proceedings prior to the beginning of negotiations, as it is a right recognized and guaranteed by law. Moreover, the law does not oblige the defendant to enter into a plea bargain regardless of the evidence in the case, the crime committed, the seriousness of the charges against him or the practice of the courts. In view of these considerations, if the defendant uses the procedure of plea bargain, he is aware that he will receive an appropriate reduction of the punishment for the crime committed, a reduction which he could not have benefited from if he had not concluded such an agreement and would have chosen the trial to be conducted under the common law procedure.

From the perspective of those involved, joining this special procedure consists in protecting their reputation. Since the criminal trial takes place as a result of notifying the court with a plea bargain, by initiating this procedure it can be seen that the exposure of less favorable aspects of the personal life of the defendant is significantly reduced (Pascu \& Manea, 2015, pp. 16).

Secondly, as a result implementing the plea bargain, certain advantages of the judicial system in criminal cases are highlighted, of which we list, without being exhaustive: the administrative costs of the act of justice are much lower, given that in certain cases rather onerous expenses might be made, for example in the case of conducting an expertise, such a plea bargain therefore favoring the state by the fact that it provides the possibility of saving financial resources, as well as the accelerated settlement of criminal proceedings, compared to regular criminal proceedings.

For these reasons, the procedure of the plea bargain is a simplified form of solving criminal cases, a procedure that also offers benefits on avoiding social stigma and reducing the legal costs that the defendant will eventually have to cover.

\section{References}

Bârsan, M. M., \& Cardiş, M. M. (2015). Acordul de recunoasstere a vinovăției [The plea bargain]. Hamangiu.

Buneci, P., Şerban, G., Ciolaca, I., Dragnea, I., Vasilache, A., Crețu, S., \& Stoica, V. (2014). Noul Cod de procedură penală. Note. Corelatiii. Explicații [The new Criminal Procedure Code. Notes. Correlations. Explanations]. C. H. Beck.

Constitutional Court of Romania. (2011). Decizie nr. 1.470 din 8 noiembrie 2011 referitoare la excepția de neconstituţionalitate a dispozițiilor art. $320^{\wedge} 1$ din 
Codul de procedură penală Judgement no. 1,470 of November 8th, 2011 regarding the exception of unconstitutionality of the provisions of art. 320 ^ 1 of the Criminal Procedure Code]. Monitorul Oficial al României, 853, December 02, 2011.

Cotoi, F., \& Brutaru, V. (2014). Efectele recunoassterii vinovațtiei în dreptul penal [The effects of the admission of guilt in criminal law]. Universul Juridic.

Crişu, A. (2017). Drept procesual penal. Partea generală [Criminal procedural law. The general part] (2nd ed.). Hamangiu.

Fisher, T. (2007). The boundariers of plea bargaining: Negotiating the standard of proof. The Journal of Criminal Law and Criminology, 97(4), 943-1008.

https://scholarlycommons.law.northwestern.edu/cgi/viewcontent.cgi?refe rer=https: $/$ www.google.com $/$ \&httpsredir $=1 \&$ article $=7272 \&$ context $=$ jclc

Ghigheci, C. (2014). Principiile procesului penal în Noul Cod de procedură penală [The principles of criminal proceedings in the New Criminal Procedure Code]. Universul Juridic.

Iugan, A. V. (2015). Acordul de recunoaștere a vinovăţiei [The plea bargain]. Universul Juridic.

Magherescu, D. (2019). Recunoașterea vinovăției şi aplicarea pedepsei [Admission of guilt and application of punishment]. Hamangiu.

Olariu, M., \& Marin, C. (2019). Drept procesual penal. Partea specială [Criminal procedural law. The special part]. Universul Juridic.

Pascu, M., \& Manea, T. (2015). Acordul de recunoaştere a vinovăţiei [The plea bargain]. Universul Juridic.

Pradel, J. (2005). Le plaider coupable, confrontation des droits americain, italien et francais [Pleading guilty, confrontation of American, Italian and French law]. Revue Internationale de Droit Compare, 57(2), 473-491. https://www.persee.fr/doc/ridc 0035-3337 2005 num 57219357

Romanian Government. (2011). Ordonanța de urgență a Guvernului nr. 121/2011 pentru modificarea şi completarea unor acte normative [Emergency ordinance no. 121/2011 for the modification and completion of some normative acts]. Monitorul Oficial al României, 931, December 29, 2011.

Romanian Parliament. (2010). Legea nr. 135/2010 privind Codul de procedură penală [Law no. 135/2010 on the Criminal Procedure Code]. Monitorul Oficial al României, 486, July 15, 2010.

Romanian Parliament. (2010). Legea nr. 202/2010 privind unele măsuri pentru accelerarea soluționării proceselor [Law no. 202/2010 on some measures to accelerate the resolution of trials]. Monitorul Oficial al României, 714, October 26, 2010. 
United States Supreme Court. (1970). Brady vs. USA, case no. 397 U.S. 742, decision from May $4^{\text {th }}, 1970$.

https://supreme.justia.com/cases/federal/us/397/742/

Văduva, V. (2019). Judecata in cazul recunoasterii invinuirii Judicial proceedings in the case of admission of guilt]. Hamangiu.

Volonciu, N., \& Nicolae Uzlău, A. (2017). Codul de procedură penală comentat [Comments on the Criminal Procedure Code] ( $3^{\text {rd }}$ ed.). Hamangiu.

Volonciu, N., Vasiliu, A., \& Gheorghe, R. (2016). Noul Cod de procedură penală adnotat. Partea specială [The new Criminal Procedure Code annotated. The special part]. Universul Juridic. 